\title{
Steroids in exacerbations of asthma: tablets or inhalers?
}

\author{
Chris Griffiths
}

How should we treat exacerbations of asthma in general practice? The innovative study reported by Levy and coworkers on pp 1087-92 of this issue of Thorax raises some interesting questions. ${ }^{1}$ In a double blind, double dummy, randomised parallel group study of patients with mild to moderate exacerbations of asthma in general practice they could find no difference between the effects of a reducing course of prednisolone and $2 \mathrm{mg}$ daily of inhaled fluticasone propionate. The study was well conducted, with measurements of both lung function and symptoms. No patients experienced more than minor adverse effects with either medication. The authors suggest that inhaled fluticasone propionate may be considered as first line treatment for mild exacerbations of asthma in general practice.

Does this study mean we should change our practice? What of any methodological problems? Firstly, the authors acknowledge that their choice of prednisolone dosing ( $40 \mathrm{mg}$, tapering by $5 \mathrm{mg}$ every other day) could be suboptimal. In a double blind study $\mathrm{Webb}^{2}$ found a two week non-tapering course of $0.6 \mathrm{mg} / \mathrm{kg}$ prednisolone (equivalent to $42 \mathrm{mg}$ daily for a $70 \mathrm{~kg}$ patient) to be more effective than lower doses. Rowe et al, in a meta-analysis of studies of steroid treatment in asthma exacerbations, found greater benefit with higher doses of prednisolone. ${ }^{3}$ New treatments are best compared with a "gold standard"; whilst it is difficult to define this for oral prednisolone in exacerbations of asthma, a larger dose without tapering ${ }^{4}$ would have been more appropriate for comparison.

Secondly, the authors found it difficult to recruit patients to the study and ended with only $57 \%$ power to detect a difference between treatments. As Altman and Bland 5 point out, absence of evidence is not evidence of absence. Lack of power here means danger of a type 2 error - we may be missing a difference between the two treatments. This is important since there was a trend towards greater improvement in the group treated with oral steroid.

What of the safety aspects? An underlying assumption by the authors of this paper is that $2 \mathrm{mg}$ of fluticasone propionate by inhalation is superior, in terms of potential adverse effects, to a tapering regime of oral prednisolone. While this is almost certainly true, $2 \mathrm{mg}$ of fluticasone propionate represents a substantial dose of a very potent topical steroid. Whilst gastrointestinal absorption of fluticasone propionate is minimal, pulmonary absorption is significant, producing effects on the hypothalamopituitary-adrenal axis which, on a microgram equivalent basis, are greater than or equal to those of other inhaled steroids. ${ }^{6-10}$

Avoiding the use of oral steroids where possible is attractive to doctors and patients alike. The superior safety record of inhaled corticosteroids over chronic oral steroid treatment is well established. ${ }^{11}$ Whether occasional use of rescue oral steroids in patients maintained on inhaled steroids has any clinically significant adverse effects is less clear. Patients recruited to this study had mild to moderately severe asthma (three quarters were on less than $1 \mathrm{mg}$ daily of inhaled steroid and had experienced between zero and two exacerbations in the last year). The study addressed relatively mild exacerbations (all but 11 of over 400 patients at entry to the study had peak expiratory flow rates after bronchodilator of $>60 \%$ of best or expected).
It seems unlikely that such infrequent short courses of either oral steroids or high dose fluticasone propionate in these patients would provoke long term harm. Gathering data on adrenal function in a general practice based study such as this would have been difficult, but the results would have been of considerable interest.

What of cost implications? A two week course of fluticasone propionate treatment in this context costs about 70 times that of a course of oral prednisolone. ${ }^{12}$ In the management of chronic stable asthma there seems little to choose between the efficacy of fluticasone propionate compared with beclomethasone dipropionate and budesonide, ${ }^{6-9}$ while relative safety aspects are still being debated. ${ }^{13}$ Switching patients established on inhaled beclomethasone dipropionate or budesonide to fluticasone propionate to manage an exacerbation could easily lead to them remaining on the more expensive but no more effective preparation afterwards. With an average general practitioner seeing over 30 exacerbations a year, this has important cost implications for the NHS overall and for general practitioners striving to keep within their prescribing budget limits.

What do we know about exacerbations of asthma in general practice? Firstly, they are common and not always optimally treated by general practitioners ${ }^{14}$ (but we may be getting better ${ }^{15}$ ). Secondly, patients often reach hospital without starting oral steroids or increasing their prophylaxis, ${ }^{16}$ although many refer themselves rather than seeking out their general practitioner. ${ }^{17}$ Thirdly, many general practitioners are poorly equipped to deal with exacerbations, carrying neither peak expiratory flow meters nor spacers/nebulisers. ${ }^{18}$ Fourthly, and perhaps most importantly, early use of rescue oral steroids (oral is as effective as intravenous) ${ }^{19}$ reduces the chances of admission to hospital. In a high quality meta-analysis Rowe et al found that given, for instance, a baseline risk of admission to hospital of one out of every five patients with exacerbations seen in casualty departments or primary care, we need to treat only about 11 patients with rescue oral steroids to prevent one admission. ${ }^{3}$ With admission rates for asthma running at double the national average in some areas, ${ }^{19}$ there is clearly room for improvement in the primary care management of exacerbations of asthma.

Finally, what else does this study suggest we need to know? As the authors point out, we should explore the potential benefits of high dose inhaled steroids in patients with more severe exacerbations. Other groups with exacerbations worth studying are adolescents and children (particularly those at puberty who may be more susceptible to the effects of regular oral steroids ${ }^{20}$ ) and adults with more severe chronic asthma. Benefits in the last group are likely to be limited since they will tend already to be on near maximal inhaled therapy, limiting the room for an increase in dosage. We should also compare the efficacy of other inhaled steroids with that of a more appropriate dose of oral steroid in managing asthma exacerbations.

In conclusion, this study provides a promising start but further studies are needed before changing the recommendations for managing moderate exacerbations of asthma in general practice. 
I am grateful to Gene Feder, Sean Hilton, Neil Barnes, Brian Lipworth and Martin Eccles for helpful advice.

Department of General Practice

CHRIS GRIFFITHS

and Primary Care,

Medical College of St Bartholomew'

and the Royal London Hospitals,

London EC1M 6BQ, UK

1 Levy ML, Stevenson C, Maslen T. Comparison of short courses of ora prednisolone and fluticasone propionate, $1 \mathrm{mg}$ twice daily, in the treatment of adults with acute exacerbations of asthma in primmary care. Thorax of adults with acute

2 Webb J. Dose response of patients to oral corticosteroid treatment during exacerbations of asthma. BMF 1986;292:1045-7.

3 Rowe BH, Keller JL, Oxman AD. Effectiveness of steroid therapy in acute exacerbations of asthma: a meta-analysis. Am f Emerg Med 1992;10 301-10.

4 O'Driscoll BR, Kalra S, Wilson M, Pickering CAC, Carroll KB, Woodcock AA. Double blind trial of steroid tapering in acute asthma. Lancet 1993 341:342-7.

5 Altman DG, Bland JM. Absence of evidence is not evidence of absence. BMF 1995;311:485.

6 Ayers JG, Bateman ED, Lundback B, Harris TA. High dose fluticasone propionate, $1 \mathrm{mg}$ daily, versus fluticasone propionate, $2 \mathrm{mg}$ daily, or budesonide, $1.6 \mathrm{mg}$ daily, in patients with chronic severe asthma. Eur Respir f 1995;8:579-86.

7 Boe J, Bakke P, Rodolen T, et al. High dose inhaled steroids in asthmatics: moderate efficacy gain and suppression of the hypothalamic-pituitaryadrenal (HPA) axis. Eur Respir f 1994;7:2179-84.
8 Barnes NC, Marone G, Di Maria GU, Visser S, Utama I, Payne SL, on behalf of an International Study Group. A comparison of fluticasone propionate, $1 \mathrm{mg}$ daily, with beclomethasone dipropionate, $2 \mathrm{mg}$ daily, in the treatme of severe asthma. Eur Respir $\mathcal{7} 1993 ; 6: 877-84$.

9 Fabbri L, Burge PS, Croonenborgh L, Warlies F, Weeke B, Ciaccia A, al. Comparison of fluticasone propionate with beclomethasone dipropionate in moderate to severe asthma treated for one year. Thorax 1993;48:817-23.

10 Clark DJ, Grove A, Cargill RI, Lipworth BJ. Comparative adrenal suppression with inhaled budesonide and fluticasone propionate in adult asthmatice patients. Thorax 1996;51:262-6.

11 Barnes PJ, Pedersen S. Efficacy and safety of inhaled corticosteroids in asthma. Am Rev Respir Dis 1993;148:S1-26.

12 British Medical Association, Royal Pharmaceutical Society of Great Britain British National Formulary No 31. London: BMA, RPSGB, 1996.

13 Jackson C, Lipworth B. Optimizing inhaled drug delivery in patients with asthma. Br f Gen Pract 1995;45:683-7.

14 Neville R, Clark R, Hoskins G, Smith B for General Practitioners in Asthm Group. National asthma attack audit. BMf 1992;306:559-62.

15 Neville R, Clark R, Hoskins G, Smith B. GPIAG national audit of asthma attacks. Asthma in General Practice 1995;3:8

16 Blainey D, Lomas D, Beale A, Partridge $M$. The cost of acute asthma how much is preventable? Health Trends 1991;22:151-3.

17 Levy ML, Robb M, Bradley JL, Winter RJD. Presentation and self management in acute asthma: a prospective study in two districts. Thorax 1993;48:460-1.

18 Evans SA, Stoner J, Hardy C. Are general practitioners equipped to manage acute severe asthma? BMF 1994;309:1486.

19 Griffiths CJ, Naish J, Sturdy P, Pereira F. Prescribing and hospital admission in east London. BMF 1996; 312:481-2.

20 Allen DB, Mullen M, Mullen B, A meta-analysis of the effect of oral and inhaled corticosteroids on growth. F Allergy Clin Immunol 1994;93:967-76. 